UDC 004.33(035)

Akhmetov B. B. ${ }^{1}$, Lakhno V. A. ${ }^{2}$, Malyukov V. P. ${ }^{3}$

${ }^{1} \mathrm{PhD}$, Associate Professor, Rector of the Caspian State University of Technologies and Engineering named after Sh. Yessenov, Aktau, Kazakhstan

${ }^{2}$ Dr. Sc., Professor, Head of Department of cybersecurity, European University, Kyiv, Ukraine ${ }^{3}$ Dr. Sc., Associate Professor, Professor, Department of Informatics Systems, Mathematics Disciplines, European University, Kyiv,

\title{
MODEL OF INVESTMENT STRATEGIES IN CYBER SECURITY SYSTEMS OF TRANSPORT SITUATIONAL CENTERS
}

Actuality. The actual task of finding the optimal strategy for control the procedure of mutual financial investments to the situation center for cyber security on transport.

The aim of the work - the development of a model for a decision support system on the continuous mutual investment in a cyber security situational center, which differs from the existing ones by solving a bilinear differential quality game with several terminal surfaces.

Method. In order to achieve the goal there was used a discrete-approximation method for solving a bilinear differential quality game with dependent motions. Application of this method in the developed decision support system, unlike existing ones, gives concrete recommendations $\mathrm{ft}$ choosing control decisions in the investment process.

Results - the proposed model gives concrete recommendations at choosing strategies in the investment process at the creation of a protected situational center. In the course of the computational experiment, there was considered a new class of bilinear differential games that allowed adequately to describe the process of investing in cyber security means of situational transport centers in Kazakhstan and Ukraine.

Conclusions. For the first time, there was proposed a model describing the process of mutual investment based on the solution of bilinear equations and a differential quality game with several terminal surfaces. Considered the peculiarity of the differential game on the example of mutual investment in the means of cyber security of the situational transport center. In this case, the right-hand side of the system of differential equations is represented in the form of bilinear functions with arbitrary coefficients. The model allows to predict the results of investment and to find strategies for managing the investment process in the protection and cyber security systems of the situational transport center.

Keywords: decision support system, model, bilinear functions, mutual investment, cyber security, situational transport center.

\section{NOMENCLATURE}

CICS - critically important computer systems;

CS - cyber security;

ISS - information security system;

DSS - decision support system;

$\mathrm{SC}$ - situational center;

$a_{1}$ - coefficient determining the interest payment for

the financial resource of the second investor (2nd) to the first investor (1st);

$a_{2}$ - coefficient determining the interest payment for the financial resource of the first investor (1nd) to the second investor (1st);

$g^{*}$ - coefficient determining the beam balance;

$k_{d}$ - the dollar exchange rate in relation to the national currency (hryvnia, tenge, etc.);

$M_{0}$ - terminal set, which determines the end of investment by the 2nd investor;

$N_{0}$ - terminal set, which determines the end of investment by the 1 st investor;

$r_{1}$ - coefficient determining the share of return of the financial resource of the 2nd investor to the 1st one;

$r_{2}$ - coefficient determining the share of return of the financial resource of the 1 st investor to the 2 st investor;

$R_{+}^{2}$ - positive ortant;

$t$ - time parameter;

$u$ - control parameter of the 1st investor;

$u_{*}$ - optimal strategy of the 1st investor;

$v$ - control parameter of the 2nd investor;
$W_{1}$ - a set of preferences for the 1st investor;

$W_{2}$ - a set of preferences for the 2nd investor;

$z_{1}$ - the value of the financial resource of the 1 st investor;

$z_{2}$ - the value of the financial resource of the 2 nd investor;

$\alpha_{1}$ - the growth rate of the financial resource of the 1st investor;

$\alpha_{2}$ - the growth rate of the financial resource of the 2 nd investor

$\beta_{1}$ - coefficient determining the share of repayment of the debt of the 1 st investor to the 2 nd investor;

$\beta_{2}$ - coefficient determining the share of repayment of the debt of the 2 nd investor to the 1 st investor.

\section{INTRODUCTION}

Nowadays, many projects in the field of transport control are developing in the direction of creating large situational cents (SC) that provide solutions to specific tasks, in particular, the protection of critically important computer systems (CICS) of the transport industry. Investing in innovative projects, for example, in the field of cyber security (CS) and information security, is characterized by a high degree of uncertainty and riskiness [1, 2]. In work [1] there is noted that many investors in the CS sector face to chaotic and uncertainty choosing an effective investment strategy and method of risk control. Many enterprises and companies engaged in servicing CICS, in particular, on transport, spending more on information security systems (ISS) and CS, do not feel confident that the chosen investment strategy 
makes the infrastructure of information and communication systems really safe [2].

The last one, in particular, is connected with the lack of practically applicable models, taking into account the ways of finding different variants of strategies in mutual financial investment of CS objects [3, 4]. Similar problems arose at choosing mutual investment strategies in the SC for Kazakhstan, Ukraine, and other countries actively engaged in the development of ISS for CICS. In this regard, it is urgent to develop new models for intellectualized computer decision support systems (DSS) that adequately describe and evaluate investment strategies in the CS CICS.

The object of the research is the process of mutual financial investment in the situational center for transport cyber security.

The aim of this work was to develop a model for decision support systems for continuous mutual investment in a cyber security situational center, which differs from existing ones by solving a bilinear differential quality game with several terminal surfaces.

\section{PROBLEM STATEMENT}

There is considered the model for the decision support systems on continuous mutual investment in means of the CS of the SC of transport. The model is based on solving a bilinear differential quality game with two terminal surfaces. Mathematical statement: there are two players that control a dynamic system, given by a system of bilinear differential equations with dependent motions. The sets of strategies of players $U, V$ are determined, respectively. Two terminal surfaces are defined. The aim of the first player is to put the dynamic system using its control strategies on the terminal surface $M_{0}$, despite the actions of the second player. The aim of the second player is to put the dynamic system through its control strategies to the terminal surface, no matter how the first player acts. The solution is to find a set of initial states of objects and their strategies that allow objects to put the system to that or another surface. The solution of such systems of differential equations can not be found using the Cauchy formula. For the right-hand sides of differential equations with arbitrary coefficients of results on bilinear differential games, particulaliy such differential equations are used in our model, it was not obtained.

\section{LITERATURE REVIEW}

The problem of effective financial investment in the CS systems and the protection of CICS is one of the most important in the security sphere of almost all states [1, 2]. A large number of researches have been devoted to this subject $[3,4]$. However, it should be noted that the authors [4-6] did not offer any real recommendations on the development of mutual financial investment strategies in the CS CICS [4-6]. A separate direction of the researches in this area was the work devoted to the application of various expert systems [7-9] and DSS [10, 11] for the selection of rational investment strategies in the ISS and CS. The approaches developed by the authors $[12,13]$ and $[7,8,14]$ at solving this problem do not allow to find effective recommendations and investment control strategies in the CS. This circumstance necessitates the development of new models for DSS, which would provide an opportunity to find optimal strategies for mutual financial investment in the means of protecting the CICS. This can be achieved, in particular, by applying methods of the differential quality games theory with several terminal surfaces $[11,15]$. It should be noted that for such differential games the approaches outlined in works $[1,4,5]$ are not applicable, because within the framework of decisions the enemy player can apply measurable controls, and in the work under consideration there are allowed any controls including non-measurable functions.

As the analysis of the latest researches in this area showed the problem of further development of DSS models in the tasks of continuous mutual investment in the ISS and CS CICS, in particular, the situational center on transport, remains relevant.

\section{MATERIALS AND METHODS}

An investor from a country, where the US dollar is in cash, having free capital, is trying to choose the most preferable options for his placement. In order to do this, he chooses a counterparty, i.e. an object for investing his own funds, for example, in Kazakhstan, where the tenge is in cash. The object of investment are ISS and CS of SC on transport, as one of the components of the critical infrastructure of the state. The investor wants to increase his capital, the counterparty - to improve their financial and economic level.

If such an objective for an investor arises regularly, it is advisable to use DSS in the decision-making process related to investing. The formalization of the investment process is given under the assumption that the investor is an investment company, a counterparty is a financial structure in another country. We call this structure a financial corporation.

An investment company, having some free resources (its investment capital), increases them by $\alpha_{1}$ times. Then it is necessary to decide what part of these resources it will invest in active operations. These operations are the allocation of resources in the investment projects of the corporation in the sphere of CS of the SC and in the repayment of the debt that the company has at that time. We will consider that the corporation does the same with respect to this investment company. The interaction between the company and the corporation will be described under the following assumptions: 1) the investment company controls financial resources $z_{1}$ estimated in dollars (USD); 2 ) the corporation controls financial resources $z_{2}$ estimated in national currency (for example, tenge (Kazakhstan) or hryvnia (Ukraine), 3) during the interaction, the ratio of the dollar to the national currency (dollar exchange rate) remains constant.

After that, the investment company and the counterparty identified the share of resources allocated for mutual active operations, their interaction is determined through the following system of differential equations:

$$
\begin{aligned}
& d z_{1}(t) / d t=-z_{1}(t)+\alpha_{1}(t) \cdot z_{1}(t)+\left[\left(1-\beta_{1}(t)\right) \cdot\left(a_{1}(t)+r_{1}(t)\right)-1\right] \times \\
& \times u(t) \cdot \alpha_{1}(t) \cdot z_{1}(t)+\left[1-\left(a_{2}(t)+r_{2}(t)\right) \cdot\left(1-\beta_{2}(t)\right)\right] \times \\
& \times v(t) \cdot \alpha_{2}(t) \cdot z_{2}(t) / k_{d}
\end{aligned}
$$


$d z_{2}(t) / d t=-z_{2}(y)+\alpha_{2}(t) \cdot z_{2}(t)+\left[\left(1-\beta_{2}(t)\right) \cdot\left(a_{2}(t)+r_{2}(t)\right)-1\right] \times$

$\times v(t) \cdot \alpha_{2}(t) \cdot z_{2}(t)+\left[1-\left(a_{1}(t)+r_{1}(t)\right) \cdot\left(1-\beta_{1}(t)\right)\right] \times$

$\times u(t) \cdot \alpha_{1}(t) \cdot z_{1}(t) / k_{d}$.

Therefore, at time $t$ the company's value $d z_{1}(t) / d t$ (in dollars $-\$$ ) will be equal to the sum of the following values: $\alpha_{1}(t) \cdot z_{1}(t)$; percents $a_{1}(t) \cdot\left(1-\beta_{1}(t)\right) \cdot u(t) \cdot \alpha_{1}(t) \cdot z_{1}(t)$ for invested financial resources $\left(1-\beta_{1}(t)\right) \cdot u(t) \cdot \alpha_{1}(t) \cdot z_{1}(t)$ of the company; $r_{1}(t) \cdot\left(1-\beta_{1}(t)\right) \cdot u(t) \cdot \alpha_{1}(t) \cdot z_{1}(t)-$ share of the "returned" investment resource $\left(1-\beta_{1}(t)\right) \cdot u(t) \cdot \alpha_{1}(t) \cdot z_{1}(t)$ of the company; "unreturned" asset (investment)

$\left\{\left(1-r_{2}(t)\right) \cdot\left(1-\beta_{2}(t)\right) / k_{d}\right\} \cdot v(t) \cdot \alpha_{2}(t) \cdot z_{2}(t) \quad$ of $\quad$ the corporation (in $\$$ ); $\left\{\beta_{2}(t) / k_{d}\right\} \cdot v(t) \cdot \alpha_{2}(t) \cdot z_{2}(t)$ - the repayment of the corporation debt to the company, from which (out of the amount) there is deducted: financial resource $z_{1}(t)$; the value $u(t) \cdot \beta_{1}(t) \cdot \alpha_{1}(t) \cdot z_{1}(t)$, allocated to repay the debt that the company had at time $t$ to the corporation, as well as the amount $u(t) \cdot\left(1-\beta_{1}(t)\right) \cdot \alpha_{1}(t) \cdot z_{1}(t)$, allocated for investment at time $t ; \quad\left\{a_{2}(t) \cdot\left(1-\beta_{2}(t)\right) / k_{d}\right\} \cdot v(t) \cdot \alpha_{2}(t) \cdot z_{2}(t) \quad$ - interest payment for investment resources $\left\{\left(1-\beta_{2}(t)\right) / k_{d}\right\} \cdot v(t) \cdot \alpha_{2} \cdot z_{2}(t)$ of the corporation.

The value $d z_{2}(t) / d t$ (national currency, tenge, hryvnia, etc.) at time $t$ will be equal to the sum of the following terms of the quantities: $\quad \alpha_{2}(t) \cdot z_{2}(t) ; \quad$ percents $a_{2}(t) \cdot\left(1-\beta_{2}(t)\right) \cdot v(t) \cdot \alpha_{2}(t) \cdot z_{2}(t)$ for invested financial resources $\left(1-\beta_{2}(t)\right) \cdot v(t) \cdot \alpha_{2}(t) \cdot z_{2}(t)$ of the corporation; $r_{2}(t) \cdot\left(1-\beta_{2}(t)\right) \cdot v(t) \cdot \alpha_{2}(t) \cdot z_{2}(t)$ - share of the "returned" investment resource of the company $\left(1-\beta_{2}(t)\right) \cdot v(t) \cdot \alpha_{2}(t) \cdot z_{2}(t)$; “unreturned" asset $\left(1-r_{1}(t)\right) \cdot\left(1-\beta_{1}(t)\right) \cdot u(t) \cdot k_{d} \cdot \alpha_{1}(t) \cdot z_{1}(t)$ of the corporation; the values $u(t) \cdot \beta_{1}(t) \cdot k_{d} \cdot \alpha_{1}(t) \cdot z_{1}(t)$, characterized the repayment of the company debt from which there is deducted: financial resource $z_{2}(t)$; the sum $v(t) \cdot \beta_{2}(t) \cdot \alpha_{2}(t) \cdot z_{2}(t)$, allocated to repay the debt of the corporation to the company at time $t ; \quad\left(1-\beta_{2}(t)\right) \cdot v(t) \cdot \alpha_{2}(t) \cdot z_{2}(t)$ - the corporation's funds for conducting active operations (investments); $a_{1}(t) \cdot\left(1-\beta_{1}(t)\right) \cdot k_{d} \cdot u(t) \cdot \alpha_{1}(t) \cdot z_{1}(t)-$ interest payment for investment resources $\left(1-\beta_{1}(t)\right) \cdot u(t) \cdot \alpha_{1}(t) \cdot z_{1}(t)$ of the company.

Interaction ends when the conditions are fulfilled:

$$
\begin{gathered}
\left(z_{1}(t), z_{2}(t)\right) \in M_{0}, \\
\left(z_{1}(t), z_{2}(t)\right) \in N_{0} .
\end{gathered}
$$

It is assumed that

$$
\begin{aligned}
& M_{0}=\left\{\left(z_{1}, z_{2}\right):\left(z_{1}, z_{2}\right) \in R_{+}^{2}, z_{1}>0, z_{2}=0\right\}, \\
& N_{0}=\left\{\left(z_{1}, z_{2}\right):\left(z_{1}, z_{2}\right) \in R_{+}^{2}, z_{1}=0, z_{2}>0\right\} .
\end{aligned}
$$

The following options are considered: 1) loss of investment resources of the corporation, but the investment company multiplied its capital (for example, with a decrease of the national currency exchange rate);2) loss of the capital of the investment company, but the corporation multiplied its capital (for example, with improper selection of hardware and software ISS and CS). If the conditions (3) and (4) are not fulfilled, the investor interaction continues.

Further we accept: the investment company - the player (I); the corporation - the player (II). Interaction of players is considered within the framework of a positional differential game with complete information [8, 11, 13]. Within the framework of this scheme, the interaction "generates" two tasks - from the point of view of the first confederate player and from the point of view of the second confederate player. Because of symmetry, it suffices to consider one of them. For example, from the point of view of the first confederate player. For this, we will define the pure strategies of the first confederate player. Denote by $T=[0, M]-$ the time segment, i.e. a set characterizing the area of the time parameter; $\mathrm{M}-\mathrm{a}$ positive real number.

Definition. The pure strategy of the first confederate player is the function $u: T \cdot[0,1] \cdot[0,1] \rightarrow[0,1]$, which designate the state of information (position) $\left(t,\left(z_{1}(0), z_{2}(0)\right)\right)$ as the value $u\left(t,\left(z_{1}(0), z_{2}(0)\right)\right): 0 \leq u\left(t,\left(z_{1}(0), z_{2}(0)\right)\right) \leq 1$.

The pure strategy of the first confederate player is the function (rule) which designate the state of information at the moment $t$ the value $u\left(t,\left(z_{1}(0), z_{2}(0)\right)\right)$, that determines the amount of the resource (capital) value of the first player that he allocated to "invest" the second player, in our case ISS and CS SC on transport. With regard to the knowledge of the enemy player (within the framework of the positional game scheme), there are made no assumptions, which is equivalent to the fact that the enemy player chooses his control effect $u(t)$ based on any information. After defining the strategies in task 1 it is necessary to determine the set of preference for the first player. Considering the fact that for the description of the proposed approach it is enough to confine with a qualitative description, the set of preferences $W_{1}$ of the first player. We assume that $W_{1}$ - a set of such initial resources $\left(z_{1}(0), z_{2}(0)\right)$ of players that have the property: for such initial states there is a strategy of the first player, which, for any realizations of the strategy of the second player, "leads", at one of the moments of time $t$, the state of the system $\left(z_{1}(t), z_{2}(t)\right)$ when will be fulfilled the condition (3). Moreover, the second player does not have a strategy that can "lead" to the fulfillment of condition (4), at one of the preceding moments of time $t$. The strategy of the 
first player with this property is called optimal. Suppose that for any moment of time $t$ the following conditions are fulfilled: $\alpha_{1}(t)=\alpha_{1} ; \quad \alpha_{2}(t)=\alpha_{2} ; \quad \beta_{1}(t)=\beta_{1} ; \quad \beta_{2}(t)=\beta_{2} ;$ $r_{1}(t)=r_{1} ; \quad r_{2}(t)=r_{2}$. Accept: $q_{1}=\left(1-\beta_{1}\right) \cdot\left(a_{1}+r_{1}\right)-1 ;$ $q_{2}=\left(1-\beta_{2}\right) \cdot\left(a_{2}+r_{2}\right)-1$. The following cases are possible: a) $\quad q_{1} \geq 0 ; q_{2} \geq 0$; $\quad$ b) $\quad q_{1} \prec 0 ; q_{2} \prec 0$; c) $q_{1} \succ 0 ; q_{2} \leq 0$; d) $q_{1} \leq 0 ; q_{2} \succ 0$. Different ratios of other interaction parameters are possible, for example, $\alpha_{1}, \alpha_{2}$. We give the solution of the game, i.e. the sets of preferences and optimal strategies for the first player.

For the case a) we will obtain:

$$
W_{1}=\left\{\left(z_{1}(0), z_{2}(0)\right):\left(z_{1}, z_{2}\right) \in \operatorname{int} R_{+}^{2}, z_{2}(0)<w^{*} \cdot z_{1}(0)\right\}(7)
$$
for

$$
w^{*}=\left\{\begin{array}{l}
-\left[q_{2} \cdot \alpha_{2}+\alpha_{2}-q_{1} \cdot \alpha_{1}-\alpha_{1}\right] /\left[2 q_{2} \cdot \alpha_{2}\right]+ \\
\left.\sqrt[2]{\left\{\left[\left\{q_{2} \cdot \alpha_{2}+\alpha_{2}-q_{1} \cdot \alpha_{1}-\alpha_{1}\right] / 2 q_{2} \cdot \alpha_{2}\right\}^{2}+\left(q_{1} \cdot \alpha_{1}\right) /\left(q_{2} \cdot \alpha_{2}\right)\right\}}\right\} ; ;
\end{array}\right.
$$

$u *\left(z_{1}, z_{2}\right)=\left\{1, z_{2}<w \cdot z_{1},\left(z_{1}, z_{2}\right) \in \operatorname{int} R_{+}^{2}\right\}$ and is not defined otherwise $\}$.

In cases b) and c) a set $W_{1}$ is empty.

In case c) and $\alpha_{2}>\alpha_{1}+q_{1} \cdot \alpha_{1}$ we will obtain

$$
\begin{aligned}
& W_{1}=\left\{\left(z_{1}(0), z_{2}(0)\right):\left(z_{1}(0), z_{2}(0)\right) \in \operatorname{int} R_{+}^{2}, z_{2}(0)<\delta \cdot z_{1}(0)\right\} \text { (9) } \\
& \text { for } \quad \delta=\left(q_{1} \cdot \alpha_{1}\right) /\left(\alpha_{2}-q_{1} \cdot \alpha_{1}-\alpha_{1}\right) \text {; }
\end{aligned}
$$

$u_{*}\left(z_{1}, z_{2}\right)=\left\{1, z_{2}<\delta \cdot z_{1},\left(z_{1}, z_{2}\right) \in \operatorname{int} R_{+}^{2}\right\}$, and is not defined otherwise $\}$.

In case c) and $\alpha_{2} \leq \alpha_{1}+q_{1} \cdot \alpha_{1}$ we obtain:

$$
W_{1}=\operatorname{int} R_{+}^{2}, u_{*}\left(z_{1}, z_{2}\right)=\left\{1,\left(z_{1}, z_{2}\right) \in \operatorname{int} R_{+}^{2}\right\},
$$

and is not defined otherwise.

The task 2 is solved symmetrically (from the point of view of the second confederate player).

\section{EXPERIMENTS}

A computational experiment was performed in the PTC Mathcad 4 environment. The model was also implemented as a separate software module on the Java language, 4 . The module is available for cross-platform use as an independent software product, or as a plug-in to the DSS "SSDMI" [15].

The axis $z_{1}$ - corresponds to the currency "tenge" (or another national currency, for example, hryvnia). The axis $z_{2}$ - corresponds to the currency "dollar". The areas of preference from the point of view of the second player are "adjacent" to the areas of preference of the first player. These areas are divided among themselves by the balance beams. The beams have the following property: if a pair of states $\left(z_{1}(0), z_{2}(0)\right)$ belongs to the balance beam, then the players have strategies that allow them to be on the balance beam for all subsequent moments of time $t$. In the course of the computational experiment, in the space of variables $\left(z_{1}, z_{2}\right)$ there are balance beams. Therefore, if the interaction starts from these states, then players have strategies that allow them to stay on the balance beam. Consequently, for given values $\left(z_{1}(0), z_{2}(0)\right)$, we can find a relation to the parameters interaction, at which the pair $\left(z_{1}(t), z_{2}(t)\right)$ will be on the balance beam. If the initial states (resources) are not on the interaction balance beam, then during the computational experiment you can try to change the interaction parameters. It is required for the initial resources to be on a balance beam. The last will allow for players to continue the interaction as long as they want.

\section{RESULTS}

Fig. 1-3 shows the results for the 3 test calculations of the investment estimation in the CS system of the Situational Center for Railway Transport of the Republic of Kazakhstan.

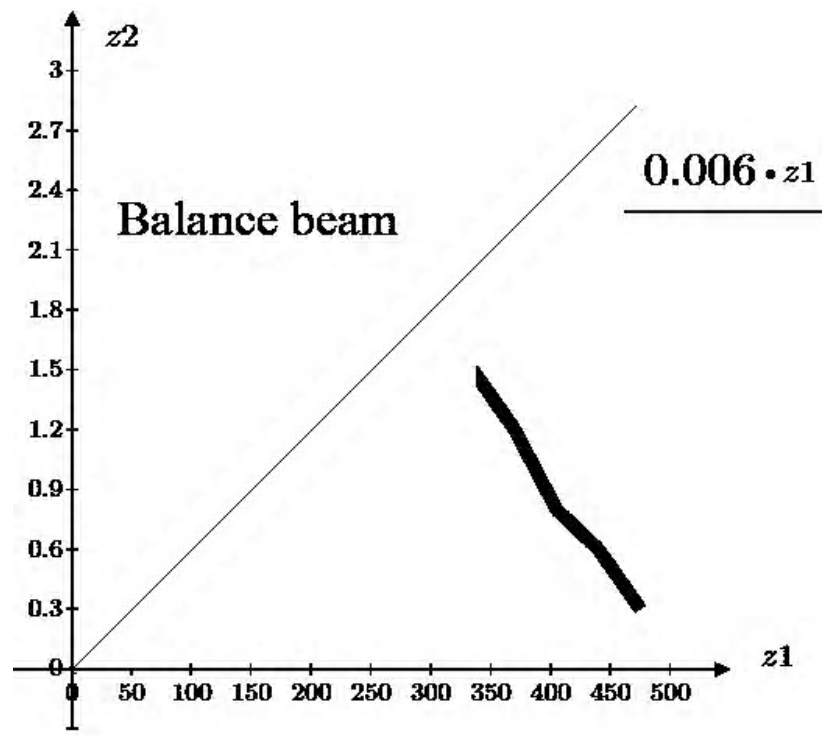

Figure 1 - Computational experiment results 1

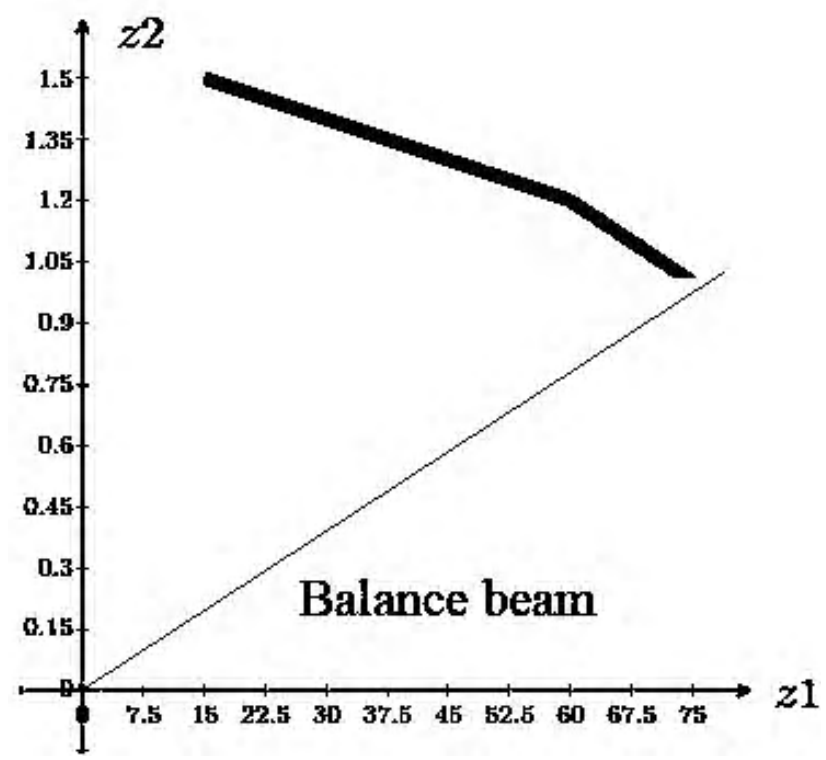

Figure 2 - Computational experiment results 2 
The first calculation for the case when the start point $\left(z_{1}(0), z_{2}(0)\right)$ belongs to the preference area of the 1st player ("Kazakhstan", the variable $x$ denotes the amount of tenge, the variable $y$ denotes the number of dollars, the exchange rate is $1 \$-335$ "tenge"). The second calculation is for the case when the start point $\left(z_{1}(0), z_{2}(0)\right)$ belongs to the preference area of the 2 nd players (the counterpart of "Kazakhstan"). The third calculation is for the case when the start point $\left(z_{1}(0), z_{2}(0)\right)$ belongs to the "balance beam", i.e. to the beam which shares the areas of the players' preference. The results of the computational experiment are presented in Table 1.

Fig. 4 presents a form for interpretation the results of decision-making support received using the DSS "SSDMI". The balance beam is shown with markers for the choice of strategies for mutual investment in the means of the CS SC of the railway transport of the Republic of Kazakhstan. Calculations: $1-g^{*}=0.006 ; 2-g^{*}=0.012 ; 3-g^{*}=0.018$.

The obtained results demonstrate the effectiveness of the proposed approach. During the testing of the model in the PTC Mathcad 4 environment, as well as in the DSS "SSDMI", there was established the correctness of the results.

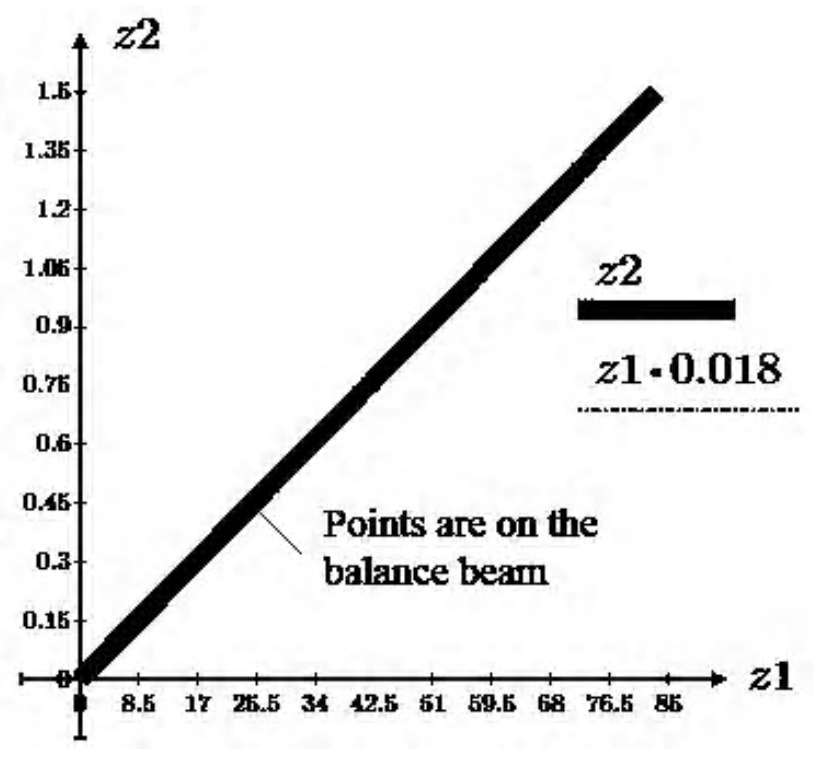

Figure 3 - Computational experiment results 3

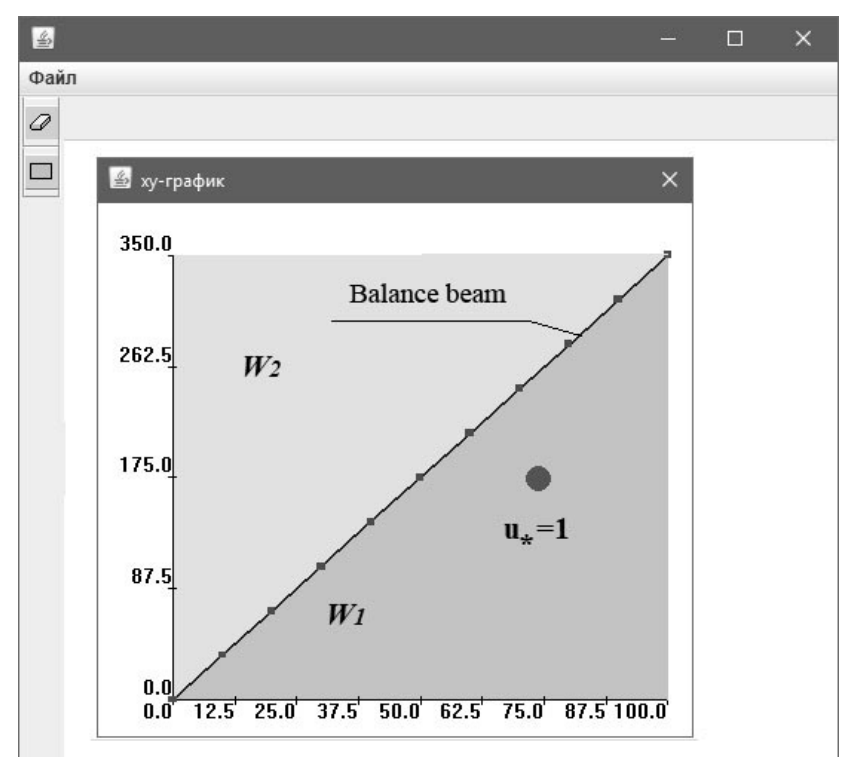

Figure 4-General view of the DSS module for the selection of strategies for mutual investment the means of CS SC

Approbation of DSS "SSDMI" was also carried out for real investment projects in the field of cyber security of Ukraine and Kazakhstan [14-16].

\section{DISCUSSION}

The prediction data obtained during the computational experiment and practical approbation of the DSS "SSDMI" module did not always coincide with the actual data $[14,15]$. This is a certain disadvantage of the approach outlined in the article. We can only try to reduce the discrepancies, in particular, through the intellectual analysis of data in DSS, and also improving the toolkit for prediction the investment processes in the CS means. It is also necessary to take into account the specifics of the investment objects, because even at the similarity of procedures there are specific features at investing in the CS means, for example, the situational center of aviation and railway transport. If this toolkit is reasonably replenished with the above-mentioned IT, then an attempt will be made more efficient for the investment process. This approach allows to do this, because it allows to select the parameters variables for the balance. The comparison of the results of the computational experiment and the practical data of investment project evaluation is compared with the results described in $[5,9,13,14]$. In the

Table 1 - The results of the computational experiment on the choice of the mutual investment strategy in the means of the CS SC of transport (on the example of the Republic of Kazakhstan)

\begin{tabular}{|c|c|}
\hline Calculations & Modeling results \\
\hline 1 & $\begin{array}{l}\left(z_{1}(0), z_{2}(0)\right)=(335,1.5) ;\left(z_{1}(1), z_{2}(1)\right)=(370,1.2) ;\left(z_{1}(2), z_{2}(2)\right)=(405,0.8) ;\left(z_{1}(3), z_{2}(3)\right)=(440,0.6) ; \\
\left(z_{1}(4), z_{2}(4)\right)=(475,0.3)\end{array}$ \\
\hline 2 & $\begin{array}{l}\left(z_{1}(0), z_{2}(0)\right)=(75,1.0) ;\left(z_{1}(1), z_{2}(1)\right)=(60,1.2) ;\left(z_{1}(2), z_{2}(2)\right)=(45,1.3) ;\left(z_{1}(3), z_{2}(3)\right)=(30,1.4) ; \\
\left(z_{1}(4), z_{2}(4)\right)=(15,1.5)\end{array}$ \\
\hline 3 & $\begin{array}{l}\left(z_{1}(0), z_{2}(0)\right)=(83.33,1.5) ;\left(z_{1}(1), z_{2}(1)\right)=(66.67,1.2) ;\left(z_{1}(2), z_{2}(2)\right)=(55.56,1.0) ;\left(z_{1}(3), z_{2}(3)\right)=(44.44, \\
0.8) ;\left(z_{1}(4), z_{2}(4)\right)=(27.77,0.5)\end{array}$ \\
\hline
\end{tabular}


course of the comparative analysis it was found that the proposed toolkit allows the participants of the investment process significantly to improve the effectiveness and predictability of their activities, on average by $12-16 \%$ [15].

\section{APPRECIATION}

The work was carried out within the framework of the grant competition for scientific and and technical projects for 2018-2020 of the Republic of Kazakhstan, registration number AP05132723 “Development of adaptive expert systems in the field of cyber security of critically important information objects".

\section{CONCLUSIONS}

There was proposed a model for the decision support system module for mutual investment in cyber security systems of a situational transport center. Unlike the existing solutions, the proposed model gives concrete recommendations at choosing strategies in the investment process of the creation of a protected situational center. If the forecast is unsatisfactory, it is possible to flexibly adjust the parameters of the investment process in the CS systems in order to achieve an acceptable financial result by the parties.

The scientific novelty of the results obtained in the article is that there was firstly considered a new class of bilinear differential games that allowed to describe adequately the process of investing in the means of the CS of situational transport centers in Kazakhstan and Ukraine. A distinctive feature of this approach, in particular, tested during the computational experiment, is the use of a solution based on a bilinear differential quality game with several terminal surfaces. The peculiarity of this differential game is that the right-hand side of the differential equations system is a bilinear function with arbitrary coefficients.

The practical significance of the obtained results is that a cross-platform software product was developed in the form of an independent module for the decision support system - SSDMI. The "SSDMI" module implements the proposed model, based on the application of methods of the differential games theory. The SSDMI module allows to reduce the discrepancies between the forecast data and the real return on investment in the funds of the CS of CICS.

Further perspectives of the development of this research is the transfer of the accumulated experience at the development of the DSS on the Android platform. This will increase the mobility of decision-making on mutual investment.

\section{REFERENCES}

1. Externalities and the magnitude of cyber security underinvestment by private sector firms: a modification of the Gordon-Loeb model / [L. A. Gordon, M. P. Loeb, W. Lucyshyn et al.] // Journal of Information Security. - 2015. - Vol. 6, № 1. - P. 24-30. DOI: $10.4236 /$ jis. 2015.61003

2. Decision support approaches for cyber security investment / [A. Fielder, E. Panaousis, P. Malacaria et al.] // Decision Support

Ахметов Б. Б. ${ }^{1}$, Лахно В. А. ${ }^{2}$, Малюков В. П. ${ }^{3}$

'Канд. техн. наук, доцент, ректор Каспійського державного університету технологій та інжинірингу ім. Ш. Есенова, Актау, Казахстан

${ }^{2}$ Д-р техн. наук, професор, зав. кафедри кібербезпеки та управління захистом інформаційних систем, Європейський університет, Київ, Україна

ЗД-р ф.-м. наук, доцент, професор кафедри інформаційних систем та математичних дисциплін, європейський університет, Київ, Україна

МОДЕЛЬ СТРАТЕГІЙ ІНВЕСТУВАННЯ В СИСТЕМИ КИБЕРБЕЗПЕКИ СИТУАЦІЙНИХ ЦЕНТРІВ ТРАНСПОРТУ

Актуальність. Реалізована актуальна задача пошуку оптимальної стратегії управління процедурою взаємного фінансового інвестування в ситуаційний центр з кібербезпеки на транспорті.

Systems. - 2016. - Vol. 86. - P. 13-23. DOI: org/10.1016 j.dss.2016.02.012

3. Meland P. H. Mitigating risk with cyberinsurance / P. H. Meland, I. A. Tondel, B. Solhaug // IEEE Security \& Privacy. - 2015. Vol. 13, № 6. - P. 38 - 43. DOI: 10.1109/MSP.2015.137

4. Smeraldi F. How to spend it: optimal investment for cyber security / F. Smeraldi, P. Malacaria // 1st International Workshop on Agents and CyberSecurity, Paris, France, 06-08 May 2014 : Proceedings. - New York : ACM, 2014. - P. 8. DOI: 10.1145/ 2602945.2602952

5. Cyber-investment and cyber-information exchange decision modeling / [D. K. Tosh, M. Molloy, S. Sengupta et al.] // High Performance Computing and Communications IEEE 7th International Symposium on Cyberspace Safety and Security (CSS), New York, 24-26 August 2015 : Proceedings. - New York : IEEE, 2015. - P. 1219-1224.

6. Alpcan T. Modeling dependencies in security risk management / T. Alpcan, N. Bambos // Risks and Security of Internet and Systems Fourth International Conference, Toulouse, France, 1922 October 2009 : Proceedings. - France : IEEE, 2009. - P. 113116. DOI : 10.1109 /CRISIS.2009.5411969

7. Peppard J. The Strategic Management of Information Systems: Puilding a Digital Strategy / J. Peppard, J. Ward. - U.K. : Wiley, 2016. - $504 \mathrm{p}$.

8. Malyukov V.P. A differential game of quality for two groups of objects / V.P. Malyukov // Journal of Applied Mathematics and Mechanics. - 1991. - Vol. 55, № 5. - P. 596-606.

9. Cassidy A. A practical guide to information systems strategic planning / A. Cassidy. - New York : CRC press, 2016. - 395 p.

10.Bonczek R. H. Foundations of decision support systems / R. H. Bonczek, C. W. Holsapple, A. B. Whinston. - USA : Academic Press, 2014. - $412 \mathrm{p}$

11. Malyukov V.P. Discrete-approximation method for solving a bilinear differential game / V.P. Malyukov // Cybernetics and Systems Analysis. - 1993. - Vol. 29, № 6. - P. 879-888.

12. Assessing survivability to support power grid investment decisions / [A. Koziolek, A. Avritzer, S. Suresh et al.] // Reliability Engineering \& System Safety. - 2016. - Vol. 155. - P. 30-43. DOI: $10.1016 /$ j.ress.2016.05.015

13. Lakhno V. Development of a Support System for Managing the Cyber Security of Information and Communication Environment of Transport / V. Lakhno, Al. Petrov, Ant. Petrov // Information Systems Architecture and Technology : 38th International Conference on Information Systems Architecture and Technology (ISAT 2017), Wroclaw, 17-19 September 2017 : proceedings. Wroclaw : Springer, 2017. - P. 113-127. DOI: 10.1007/978-3319-67229-8 11

14. Lakhno V. A. Development of a support system for managing the cyber security / V. A. Lakhno // Radio Electronics, Computer Science, Control. - 2017. - № 2. - P. 109-116. DOI: 10.15588/ 1607-3274-2017-2-12

15. Development of the decision making support system to control a procedure of financial investment / [V. Lakhno, V. Malyukov, N. Gerasymchuk et al.] // Eastern-European Journal of Enterprise Technologies. - 2017. - Vol. 6, № 3. - P. 34-41. DOI: 10.15587/ 1729-4061.2017.119259

16. Designing a decision support system for the weakly formalized problems in the provision of cybersecurity / [B. Akhmetov, V. Lakhno, Y. Boiko et al.] // Eastern-European Journal of Enterprise Technologies. - 2017. - Vol. 1, № 2. - P. 4-15. DOI: $10.15587 / 1729-4061.2017 .90506$

Article was submitted 30.12.2017 After revision 25.01.2018. 
Мета роботи - розробка моделі для системи підтримки рішень по безперервному взаємному інвестуванню в ситуаційний центр 3 кібербезпеки, яка відрізняється від наявних рішень, застосуванням білінійної диференційної гри 3 кількома термінальними поверхнями.

Метод. Для досягнення мети був застосований дискретний-апроксимаційний метод вирішення білінійної диференціальної гри якості із залежними рухами. Використання даного методу у розробленій системі підтримки рішень, на відміну від наявних, дає конкретні рекомендації при виборі управлінських рішень в інвестиційному процесі.

Результати. Запропонована модель дає конкретні рекомендації при виборі стратегії в інвестиційному процесі побудови захищеного ситуаційного центру. В ході обчислювального експерименту розглянуто новий клас білінійних диференційних ігор, що дозволило адекватно описати процес інвестування в засоби кібербезпеки ситуаційних центрів транспорту в Казахстані та Україні.

Висновки. Вперше запропонована модель, що описує процес взаємного інвестування, що базується на вирішенні білінійних відношень та диференційній грі з кількома термінальними поверхнями. Розглядається особливість диференціальної гри на прикладі взаємного інвестування в засоби кібербезпеки ситуаційного центру транспорту. При цьому права частина системи диференціальних рівнянь, представлена у вигляді білінійних функцій з будь-якими коефіцієнтами. Модель дозволяє прогнозувати результати інвестицій та пошуку стратегій управління інвестиційним процесом у системах захисту та кібербезпеки ситуаційного центру транспорту.

Ключові слова: система підтримки вирішення, модель, білінійні функції, взаємне інвестування, кібербезпека, ситуаційний центр транспорту.

Ахметов Б. Б. ${ }^{1}$, Лахно В. А. ${ }^{2}$, Малюков В. П.

${ }^{1}$ Канд. техн. наук, доцент, ректор Каспийского государственного университета технологий и инжиниринга им. Ш. Есенова, Актау, Казахстан

${ }^{2}$ Д-р техн. наук, профессор, зав. кафедры кибербезопасности и управления защитой информационных систем, Европейский университет, Киев, Украина

${ }^{3}$ Д-р ф.-м. наук, доцент, профессор кафедры информационных систем и математических дисциплин, Европейский университет, Киев, Украина

МОДЕЛЬ СТРАТЕГИЙ ИНВЕСТИРОВАНИЯ В СИСТЕМЫ КИБЕРБЕЗОПАСНОСТИ СИТУАЦИОННЫХ ЦЕНТРОВ ТРАНСПОРТА

Актуальность. Решена актуальная задача нахождения оптимальной стратегии управления процедурой взаимного финансового инвестирования в ситуационный центр по кибербезопасности на транспорте.

Цель работы - разработка модели для системы поддержки решений по непрерывному взаимному инвестированию в ситуационный центр по кибербезопасности, отличающаяся от существующих решением билинейной дифференциальной игры качества с несколькими терминальными поверхностями.

Метод. Для достижения цели был использован дискретно-апроксимационный метод решения билинейной дифференциальной игры качества с зависимыми движениями. Применение данного метода в разработанной системе поддержки решений, в отличие от существующих, дает конкретные рекомендации при выборе управленческих решений в инвестиционном процессе.

Результаты. Предложенная модель дает конкретные рекомендации при выборе стратегий в инвестиционном процессе построения защищенного ситуационного центра. В ходе вычислительного эксперимента рассмотрен новый класс билинейных дифференциальных игр, который позволил адекватно описать процесс инвестирования в средства кибербезопасности ситуационных центров транспорта в Казахстане и Украине.

Выводы. Впервые предложена модель, описывающая процесс взаимного инвестирования, основанная на решении билинейных уравнений и дифференциальной игры качества с несколькими терминальными поверхностями. Рассмотрена особенность дифференциальной игры на примере взаимного инвестирования в средства кибербезопасности ситуационного центра транспорта. При этом правая часть системы дифференциальных уравнений представлена в виде билинейных функций с произвольными коэффициентами. Модель позволяет спрогнозировать результаты инвестирования и найти стратегии управления инвестиционным процессом в системы защиты и кибербезопасности ситуационного центра транспорта.

Ключевые слова: система поддержки решений, модель, билинейные функции, взаимное инвестирование, кибербезопасность, ситуационный центр транспорта

\section{REFERENCES}

1. Gordon L. A., Loeb M. P., Lucyshyn W. et al. Externalities and the magnitude of cyber security underinvestment by private sector firms: a modification of the Gordon-Loeb model, Journal of Information Security, 2015, No. 6(1), pp. 24-30. DOI: 10.4236/jis.2015.61003

2. Fielder A., Panaousis E., Malacaria P. et al. Decision support approaches for cyber security investment, Decision Support Systems, 2016, No. 86, pp. 13-23. DOI: org/10.1016/j.dss.2016.02.012

3. Meland P. H., Tondel I. A., Solhaug B. Mitigating risk with cyberinsurance, IEEE Security \& Privacy, 2015, No. 13(6), pp. 38-43. DOI: $10.1109 /$ MSP.2015.137

4. Smeraldi F., Malacaria P. How to spend it: optimal investment for cyber security, 1st International Workshop on Agents and CyberSecurity, Paris, France, 06-08 May 2014 : proceedings. New York, ACM, 2014, pp. 8. DOI: 10.1145/2602945.2602952

5. Tosh D. K., Molloy M., Sengupta S. et al. Cyber-investment and cyber-information exchange decision modeling, High Performance Computing and Communications (HPCC), IEEE 7th International Symposium on Cyberspace Safety and Security (CSS), New York , 24-26 August 2015 : proceedings. New York, IEEE, 2015, pp. 1219-1224.

6. Alpcan T., Bambos N. Modeling dependencies in security risk management, Risks and Security of Internet and Systems (CRiSIS), Fourth International Conference, Toulouse, France, 19-22 October 2009: proceedings. France, IEEE, 2009. pp. 113-116. DOI : 10.1109 /CRISIS.2009.5411969

7. Peppard J., Ward J. The Strategic Management of Information Systems: Building a Digital Strategy, U.K. Wiley, 2016, 504 p.

8. Malyukov V.P. A differential game of quality for two groups of objects, Journal of Applied Mathematics and Mechanics, 1991, Vol. 55, No.5, pp. $596-606$
9. Cassidy A. A practical guide to information systems strategic planning, New York, CRC press, 2016, 395 p.

10. Bonczek R. H., Holsapple C. W., Whinston A. B. Foundations of decision support systems, USA, Academic Press, 2014, 412 p.

11. Malyukov V.P. Discrete-approximation method for solving a bilinear differential game, Cybernetics and Systems Analysis, 1993,Vol. 29, No. 6, pp. 879-888.

12. Koziolek A., Avritzer A., Suresh S. et al. Assessing survivability to support power grid investment decisions, Reliability Engineering \& System Safety, 2016, Vol. 155, pp. 30-43. DOI: 10.1016/ j.ress.2016.05.015

13. Lakhno V., Petrov Al., Petrov Ant. Development of a Support System for Managing the Cyber Security of Information and Communication Environment of Transport, Information Systems Architecture and Technology : 38th International Conference on Information Systems Architecture and Technology (ISAT 2017), Wroclaw, 17-19 September 2017 : proceedings. Wroclaw, Springer, 2017, pp. 113-127. DOI: 10.1007/978-3-319-67229-8 11

14. Lakhno V. A. Development of a support system for managing the cyber security, Radio Electronics, Computer Science, Control, 2017, No. 2, pp. 109-116. DOI: 10.15588/1607-3274-2017-2-12

15. Lakhno V., Malyukov V., Gerasymchuk N. et al. Development of the decision making support system to control a procedure of financial investment, Eastern-European Journal of Enterprise Technologies, 2017, Vol. 6, No. 3, pp. 24-41. DOI: 10.15587/ 1729-4061.2017.119259

16. Akhmetov B., Lakhno V., Boiko Y. et al. Designing a decision support system for the weakly formalized problems in the provision of cybersecurity, Eastern-European Journal of Enterprise Technologies, 2017, Vol. 1, No. 2, pp. 4-15. DOI: $10.15587 / 1729-4061.2017 .90506$ 